\title{
A source of conflict? Distribution of water rights in Abanico Punata, Bolivia
}

\author{
C. Saldías, S. Speelman \& G. Van Huylenbroeck \\ Department of Agricultural Economics, Ghent University, Belgium
}

\begin{abstract}
Concentration of rights and the access to water have become important issues in water and conflict debates in the Andes. In Bolivia the concentration of water takes place in an environment of increasing water scarcity and socio-economical differences between class, gender and ethnicity. Analysing the mechanisms of water right acquisition and access to water can serve as an input for policies to manage water-related conflicts. The aim of this study therefore was to investigate irrigation water allocation in 65 peasant communities that are part of 'Abanico Punata' ('Punata Fan'), an agricultural oriented region in Bolivia, in order to understand the water-related conflicts that are taking place in the area. The results show that there is a large difference in access to water between and within the communities studied. Access is mostly determined by the number and the types of water sources households have at their disposition. Many households only have access to water from the river, which is dependent on the runoff and only provides water during the wet season. Water availability improves significantly when having access to water from reservoirs, but this access depends on customary law or on investments made during the construction of the infrastructure. Considering gender and water allocation the results show that the participation of women is small compared to that of men, as on average only $30 \%$ of water rights are registered under women's names. Looking at ethnicity, the analysis shows that the determining factor in water allocation are the bonds of kinship and identification/recognition as a member of the community. Finally in relation to social class, it was shown that there is a correspondence between economic factors and water, especially because resources, mainly economic, enable a family to materialize their right, either during infrastructure creation or through purchase.
\end{abstract}

Keywords: water rights, water allocation, community, Abanico Punata, Bolivia. 


\section{Introduction}

In the Andes, struggles over water rights and benefits involve conflicts over access to and withdrawal of this extremely powerful resource, as well as over control of its management, and recognition of the legitimacy of respective authorities [1]. In these times of increasing water scarcity and competition, water rights become a pivotal issue in the struggle of local indigenous and peasant organizations to defend their livelihoods and secure their future [1-3]. Historical differences in access to water sources and more recent developments, such as demographic pressure, urbanization and the expanding role of other water-using sectors such as industry and mining explain the threatened position of indigenous and peasant systems of rules and rights in most Andean countries.

In most Andean communities, the conceptualization of a water use system is different from the physical hydraulic system and functional organization [4] conventionally known; instead locally a water use system is perceived as 'a system of rights, of obligations, and of (cultural) management regarding one or more water sources, shared among a given pool of users' [5]. Often the systems are interconnected generating multiple overlapping systems; these systems provide water to a given territory and a family might belong to several systems simultaneously [4]. In this complexity, irrigation systems are often distinguished by the kind of water they conduct, with regard to their source, the owners' group, or the way the system was made. They however mostly use (part of) a single network of canals $[3,4,6]$. These overlapping systems often give rise to different water rights within one community or watershed, and individual users can participate in different water use systems. In general, local water rights are based on a combination of historical rights, claims emerging from labor (or capital) input in (re)constructing irrigation or drinking water systems, territorial rights or individual rights linked to land ownership [3, 7]. Understanding users' rationality and local expressions of water rights in peasant and indigenous communities is of crucial importance if we want to comprehend their claim for water rights and perhaps support local empowerment processes in common property water control systems $[3,8]$.

In recent years, water governance has emerged as a conflictive political issue in Bolivia [9]. Particularly in the case of the Inter-Andean valleys in Bolivia, peasant communities face a water shortage that complicates meeting the agricultural requirements; this puts at risk their livelihood security. The importance of water for these communities and the increasing scarcity act to intensify conflicts for access to water and for control over water management. At the same time water is however also a means of empowering people and can be the driving force behind the formation of strong common property institutions grounded in shared rules and collective rights [8].

This paper focuses on water allocation practices for irrigation in 65 peasant communities of Abanico Punata (Figure 1). These communities have a complex way of managing their irrigation systems, using water originating from several surface water sources. These sources include reservoirs, springs and rivers, and a peculiar characteristic is that many of these sources are located outside the 
hydrological boundaries of the watershed. Historically and nowadays, this has led to the formation of complex 'socionatures', 'waterscapes' and 'hydrosocial networks' [11-13]. While all water sources share the same infrastructure for water delivery, each water source or group of sources has its own organisation, water rights mechanisms and management. The access to the various water sources is differentiated among, and within communities, whereby communities tend to secure rights over water sources based on historical rights claims and labor investment. This paper compares the use of these sources and rights over the sources between and within communities. Furthermore the main factors influencing water access, such as historical claims, organizational capacity, resources availability and geographical position and infrastructure are discussed. We use quantitative data from the Pucara Database [14] to evaluate water access in terms of quantity and opportunity. The first aspect looks at the quantity of water each community receives in relation to its area (in $\mathrm{mm} / \mathrm{year}$ ) and its population (in $\mathrm{m}^{3} /$ year/family). The second aspect looks at the opportunity communities have to receive water, which is evaluated in terms of the number of irrigation systems per community, and the number of times per year each system delivers water. Furthermore interviews were conducted with community members and other key informants in order to collect qualitative data regarding the process of water allocation. Specific communities were selected for in-depth interviews to draw a picture of water access within the communities.

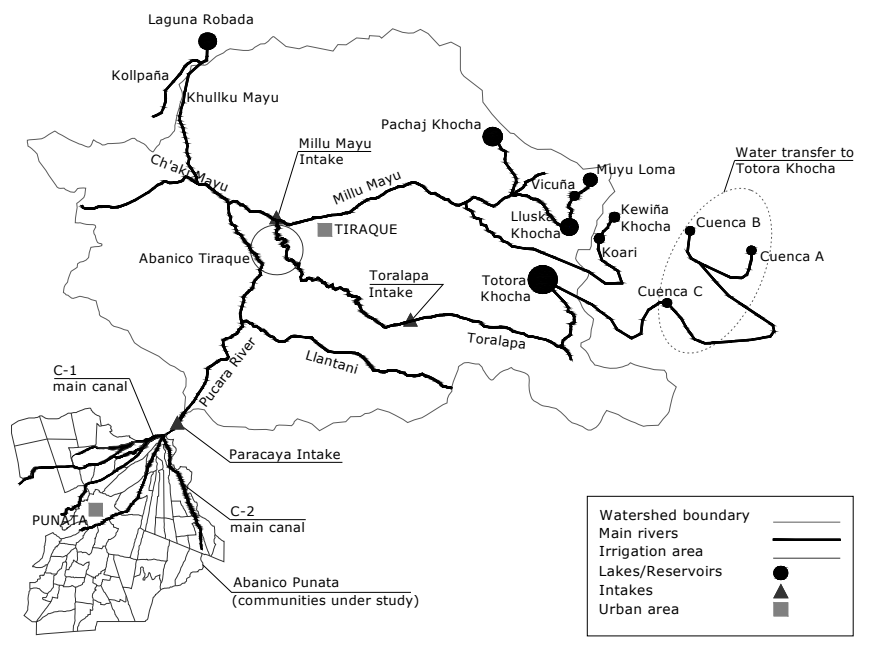

Figure 1: Schematic map of the hydrological network Abanico Punata Pucara watershed. Source: adapted from Rojas and Montenegro [10].

\section{Irrigation systems}

A first step necessary to understand and describe water access of the communities of the study area is a characterization of the existing water use 
systems. In the study area we can distinguish seven water use systems that receive surface water (Table 1). Three of them (Totora Khocha (TK), Laguna Robada (LR) and Lluska Khocha-Muyu Loma (LK-ML)) have a regulated flow regime since the water comes from reservoirs. Four have a non-regulated flow regime: their water is taken from the river (according to the distribution modalities these are called 'Mit'a', 'Rol', 'Riada' 'Pilayacu'). The use of water varies according to the characteristics of the source in terms of interval of supply, discharge, time of the year, rights and access. Reservoirs, for instance, have long supply intervals (i.e. low water donation frequency) and high discharges compared to the other sources. They are therefore usually used for land preparation. Wells have a short supply interval and low discharges. They are used for cash crop irrigation, animal watering, washing of crops, etc. These differences in frequency and quantity of access thus also determine the crops cultivated [15].

Table 1: $\quad$ Main features of the surface water use systems in Abanico Punata.

\begin{tabular}{ccccccc}
\hline Flow type & $\begin{array}{c}\text { Source } \\
\text { type }\end{array}$ & System & $\begin{array}{c}\text { Volume } \\
\left(\mathrm{hm}^{3}\right)\end{array}$ & $\begin{array}{c}\text { Discharge } \\
\text { at system } \\
\text { level (1/s) }\end{array}$ & $\begin{array}{c}\text { Period of } \\
\text { use }\end{array}$ & Uses \\
\hline Regulated & Dam & TK & 6.5 & 1600 & $\begin{array}{c}\text { Jun - } \\
\text { Dec } \\
\text { Iarch - }\end{array}$ & I; Lp \\
Dec \\
LR & 1.6 & 400 & $\begin{array}{c}\text { March - } \\
\text { Dec }\end{array}$ & I; Lp \\
\hline $\begin{array}{c}\text { Non- } \\
\text { regulated }\end{array}$ & $\begin{array}{c}\text { River } \\
\text { (Spring) }\end{array}$ & Pilayacu & 0.31 & $2-20$ & $\begin{array}{c}\text { Dec - } \\
\text { May }\end{array}$ & I; Aw; \\
\cline { 2 - 7 } & River & Mit'a & 2.70 & $20-300$ & $\begin{array}{c}\text { Dec - } \\
\text { May } \\
\text { Dec - } \\
\text { May }\end{array}$ & I; Lp \\
& Rol & 1.01 & $300-800$ & $180-200$ & I; Lr \\
\hline
\end{tabular}

I: irrigation; Lp: land preparation; Aw: animal watering; L: laundry; Lr: land recovery. Source: Adapted from Del Callejo and Vasquez [15]; Delgadillo and Lazarte [20].

The LK-ML and TK reservoirs are located within the Pucara watershed; the LR reservoir is located outside the watershed. Water from the three reservoirs is transferred to communities in Abanico Punata. For these systems one can distinguish between 1) intake and conveyance infrastructure, and 2) delivery infrastructure [16]. While the LK-ML and TK reservoirs share part of their conveyance infrastructure, LR is separate. In terms of delivery infrastructure there are two main canals starting at Paracaya intake and some secondary canals. This canal infrastructure is shared by all systems including the river and spring systems (Figure 1). Each water use system is unique in terms of its origin, history, membership, and command area. The origin of the LK-ML and LR reservoir systems is nevertheless similar, with communities organizing 
themselves to build the reservoir dams or claiming old rights over water sources $[9,17-19]$. Participation in these systems is strongly linked to community membership. The rationale behind limiting the membership to specific communities was water control, in order to avoid conflicts (e.g. water theft, losses, difficulties in management) during water delivery. Moreover in this way the access to these water use systems remains linked to the investments made by the communities in terms of labor force and money to construct the systems. In contrast, the TK system was in principle opened to all communities in Punata valley (within the boundaries set up by the project funding this system), which were willing to join.

The four water use systems of the river: 1) Pilayacu, 2) Mit'a, 3) Rol and 4) Riada are differentiated based on the river discharges (i.e. according to the water availability in the river, a different distribution modality is set in place). For instance, the Pilayacu system operates when river flow ranges between 10 and 50 $1 / \mathrm{s}$ (whereby $20 \mathrm{l} / \mathrm{s}$ is recognized as 'Pilayacu spring discharge'). This occurs when the river only contains the water from the spring. Mit'a starts running when the river discharge overpasses what is recognized as Pilayacu ( $>201 / \mathrm{s})$ and stays below $300 \mathrm{l} / \mathrm{s}[14,18]$. For the Rol system, the natural river runoff has to exceed what is established as Mit'a discharge $(300 \mathrm{l} / \mathrm{s})$. When the river flow exceeds a discharge of $800 \mathrm{l} / \mathrm{s}$ (generally during wet season) the river system is called Riada (or flood). The river discharge reaches up to $150 \mathrm{~m}^{3} / \mathrm{s}$. All these systems are obviously available during the wet season. The Pilayacu and Mit'a river water use systems date from the hacienda times. In that period landowners could take the water from the river and use it to irrigate their plots [21]. After the Agrarian Reform, these water rights were passed to peasants - former colonos as a property of the community [19]. This however implies that not all community members have rights over specific systems. The Rol scheduled system was created as a way to compensate downstream communities, not benefitting from the Pilayacu and Mit'a systems. The use of the flood - Riada finally is opened to all communities and all community members. Water is used mainly for soil recovery and availability is unpredictable, therefore there is no particular organization for the allocation.

\section{Water access at community level: quantity and opportunity}

As mentioned in the introduction, communities receive water from different sources and the access to these sources is differentiated among communities. The communities are furthermore heterogeneous in terms of area, number of households, number of irrigation systems, water rights, number of members per system, crop types, etc. We will compare the communities in terms of water quantity and water opportunity.

Water quantity is analyzed in relation to the area of the community (expressed in $\mathrm{mm} / \mathrm{year}$ ) and in relation to the population (expressed in $\mathrm{m}^{3} / \mathrm{year} /$ family). The volume of water is estimated based on hours of allocation and the discharge, taking into account only the systems for which data were available (LR, LK-ML, TK, Mit'a and Pilayacu). Ranges were established to express water quantity 
whether in $\mathrm{mm} /$ year or in $\mathrm{m}^{3} /$ family/year. The results indicate that $41.5 \%$ of the communities receive between 115 and $11 \mathrm{~mm} /$ year. A small number of communities $(10.8 \%$ ) receives considerably more water (between 640 and 326 $\mathrm{mm} /$ year), while the remainder receive between 325 and $116 \mathrm{~mm} /$ year (Figure 2a). It is noteworthy that most of the communities receiving between 115 and 11 $\mathrm{mm} /$ year are concentrated downstream, while upstream communities tend to receive more water. Regarding the amount of water per family, the results show that in most communities a modest amount of water is received per family (Figure 2b). Again the communities showing the highest values $\left(4280 \mathrm{~m}^{3} /\right.$ year) are located upstream; while values lower than $1576 \mathrm{~m}^{3} /$ year per family are found in downstream communities.

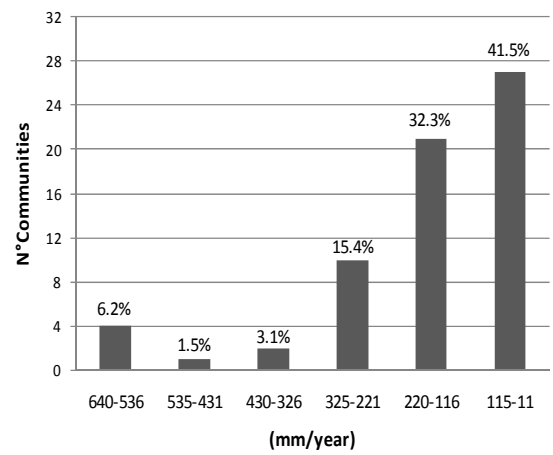

(a)

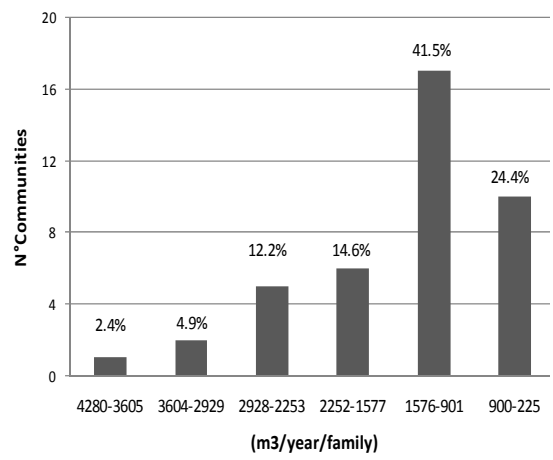

(b)

Figure 2: (a) total water access per community ( $\mathrm{mm} / \mathrm{year})$ and (b) average per family $\left(\mathrm{m}^{3} /\right.$ year/family).

Water opportunity is analyzed by the number of irrigation systems that serve the territory determined by the community boundaries and the number of times water is available from a specific source. The first parameter counts the number of systems the community has access to. This is related to the area of influence of each system. The second aspect estimates the number of times the community will receive water from the different systems. This was important since there is large difference among the systems. For instance, LR on average provides water 10 times a year, while TK provides water only 2 times a year. This aspect also reflects the community water security throughout the year. For instance a community with access to LR, TK, Mit'a, Rol and Riada has water all the year round. With respect to the number of irrigation systems, most communities have access to 3 up to 5 systems. Only one community has access to 6 systems; and two communities only have access to 2 systems (Figure $3 a$ ). The largest share $(47.7 \%)$ has access to 3 systems. The communities with access to most irrigation systems are located upstream. With respect to the number of times water is received from the different sources, results show that most of the communities $(47.7 \%)$ receive water only 2 times per year. The highest frequency is concentrated in $30.8 \%$ of the communities, which receive water between 12 and 20 times per year (Figure 3b). Clearly, there is a link between the number of 
times communities receive water from the different sources and the number of systems available within the community boundaries, i.e. communities with more systems receive water more frequently because of the difference in the source availability. For instance, Pucara receives water 20 times per year and has access to 6 systems. This is the only community benefitting from Pilayacu and it is also part of the LK-ML system with an average frequency of supply of 6 times per year. Tambillo Centro has 5 systems, one less than Pucara, but receives water 16 times per year because it belongs to LR system, which supplies water on average 10 times per year. In contrast, Jusku Molle community has 3 systems; TK is one, which supplies water on average 2 times per year.

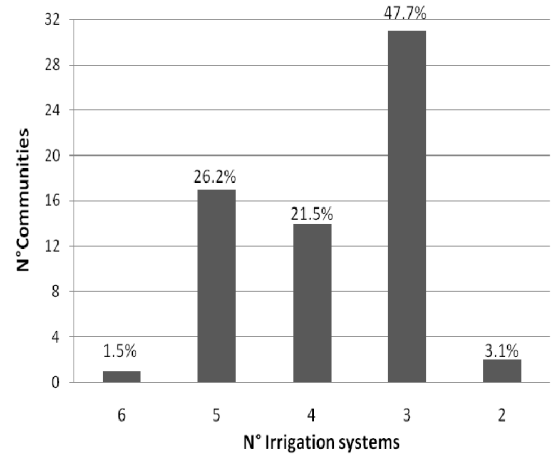

(a)

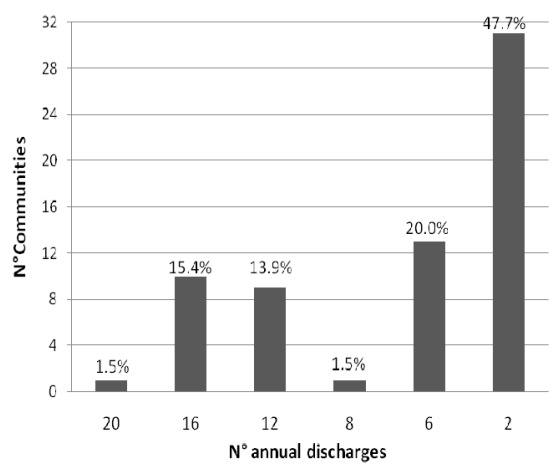

(b)

Figure 3: Number of irrigation systems communities have access to (a) and number of water deliveries per year (b).

Consequently there is a significant difference in terms of water availability according to the system-source from which communities receive water. Only 21 communities benefit from the LR and LK-ML systems, while all 65 communities benefit from the TK system, 33 from Mit'a, 1 from Pilayacu, and again all 65 from Rol and Riada. From this it can be inferred that communities with rights to systems such as LR and LK-ML have larger opportunity of having water supply throughout the year, whereas communities that depend exclusively on TK have limited opportunity. Likewise, communities with rights to the traditional systems (Mit'a and Pilayacu) have increased opportunity. Furthermore there is a near match between communities with rights to the traditional systems and LR and LK-ML reservoir systems. Geographically these communities are usually located upstream.

\section{Differences in water access within communities}

Within the communities not all the members have access to the systems in place. Water rights allocation at system level can explain how water allocation within communities developed over time. We will present an example of two communities served by the LR system and also data on water rights in relation to women. 
At system level, the mechanisms for water rights acquisition vary between the different systems. To be included as a member of a system people had to comply with certain requirements e.g. being member of the community, meet the obligations with the community, posses land to irrigate, etc. Initially, for all the systems except TK, water rights were distributed more or less homogenously among the members of the systems under the form of shares. Members could receive half a share, one share and to a lesser extent two shares. These shares represent the amount of time one has the right to irrigate, with the time allotted to one share varying between the systems. Only the Riada system has no fixed time allotment, because it varies according to water availability in the river. In all other cases water is distributed among the right holders on a rotational basis. Thus, right holders are entitled to use the full discharge of the canal during the time allotted $[21,22]$. In the reservoirs' systems, the number of shares received was related to the one's capacity to contribute to the construction of the dam in terms of labor and money. In the systems Mit'a and Pilayacu, water rights were related to the services rendered by the colonos during the hacienda time, as explained previously. For the systems Rol and Riada, water rights are purely linked to the community membership.

Over the years, the initial configuration of water rights at system level has changed and the original water rights were fragmented due to inheritances and sales. This is the main reason why nowadays one can find members with more (or less) shares. The degree of fragmentation differs between communities. For instance, for the system LR the water rights distribution in the community Wasa Mayu Grande shows that most right holders (64.9\%) have 30 minutes (one share) of time allotment to irrigate, $29.7 \%$ have right to 15 minutes (half share) and $2.7 \%$ have right to less than 10 minutes (fraction of a share) (Figure 4a). In Barrientos Grande $43.6 \%$ have right to 30 minutes, $32.7 \%$ have right to 15 minutes and $23.6 \%$ have right to 10 minutes (Figure $4 \mathrm{~b}$ ). So more fragmentation has taken place compared to Wasa Mayu.

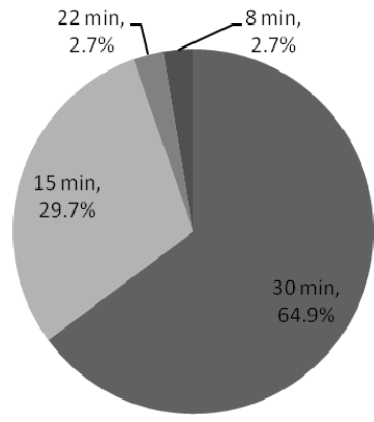

(a)

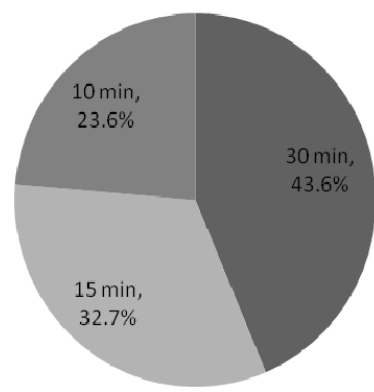

(b)

Figure 4: Water rights distribution of the system LR in the communities of Wasa Mayu Grande (a) and Barrientos Grande (b). Source: Own elaboration with data from Montaño [19]; Antezana [23]. 
Today's advantaged groups are those members of the community who have lived through the development of the different irrigation systems (generational advantage) and were able to join them because they belong to the community (kinship advantage), and had the capacity to contribute with either labor force or money (economic advantage) to materialize water rights. In contrast, disadvantaged groups constitute the members of the community that do not belong to any system because they were either too young or did not have the resources. The options they have nowadays to obtain water rights on already constituted systems depend on inheritances or purchases or the establishment of new systems in the area. Well systems are an interesting option for these people; however, they are not comparable with reservoir or river systems, mainly because of the water availability that the latter can offer. Obviously, all factors, namely generational, kinship and economic, are determinant to obtain water rights, yet the link between water and the economic factor is still strong at community level. Economic resources enable a family to materialize water rights, either during the process of constructing the system or through purchase. A family with limited economic resources hampers its ability to have water rights, whether through work, money contribution, etc. Moreover, it appears that the access to water increases the economic power and therefore influences the configuration of water allocation within the community.

\subsection{Water allocation and women}

The percentage of water rights registered under women's names is rather small, especially in the old systems such as Pilayacu, Mit'a, LR, and LK-ML. Although there are women as right holders in these systems, this is mainly the result of inheritances. The situation is slightly different in the TK system, a younger system influenced by international cooperation, which introduced aspects of gender on the agenda. The following table illustrates this situation. The highest percentage of women as right holders is presented in Molle Uma (38\%) and the lowest in Gualberto Villarroel (18\%). On average women have around 30\% of

Table 2: Water rights distribution according to sex (\%).

\begin{tabular}{|c|c|c|c|c|c|c|c|c|c|c|}
\hline \multirow{2}{*}{ Community } & \multicolumn{2}{|c|}{ LR } & \multicolumn{2}{|c|}{ LK-ML } & \multicolumn{2}{|c|}{ TK } & \multicolumn{2}{|c|}{ Mit'a } & \multicolumn{2}{|c|}{ Pilayacu } \\
\hline & $\mathrm{M}$ & $\mathrm{F}$ & $\mathrm{M}$ & $\mathrm{F}$ & $\mathrm{M}$ & $\mathrm{F}$ & $\mathrm{M}$ & $\mathrm{F}$ & $\mathrm{M}$ & $\mathrm{F}$ \\
\hline $\begin{array}{l}\text { Wasa Mayu } \\
\text { Grande }\end{array}$ & 73 & 27 & & & 72 & 28 & & & & \\
\hline $\begin{array}{c}\text { Barrientos } \\
\text { Grande }\end{array}$ & 67 & 33 & & & 72 & 28 & & & & \\
\hline Molle Uma & & & 62 & 38 & 65 & 35 & & & & \\
\hline Pucara & & & 75 & 25 & 73 & 27 & 79 & 21 & 80 & 20 \\
\hline $\begin{array}{l}\text { Gualberto } \\
\text { Villarroel } \\
\end{array}$ & & & & & 82 & 18 & & & & \\
\hline Average & 70 & 30 & 69 & 31 & 73 & 27 & 79 & 21 & 80 & 20 \\
\hline
\end{tabular}

Source: Own elaboration with data from Tuijtelaars et al. [24]; Montaño [19]; Saravia [18].

Note: M: male; F: female. 
water rights in the reservoir systems and around $20 \%$ in the traditional use of the river systems. These results also show that there are variations among communities.

\section{Conclusions}

Overall, upstream communities have advantages over those downstream. On the one hand, this is the result of historical events that have given those communities the chance to consolidate water rights to various systems, as well as to their organizational and negotiating skills at community level. On the other hand, their location favors them because they can control the river runoff and exploit groundwater. At community level water allocation is mainly influenced by 1) generational, 2) kinship and 3) economic factors. The first is related to the point in time when the different systems were consolidated to include or exclude members. The second factor incorporates social and cultural aspects of the communities. Through community's water rights the user is able to access water either through 'formal' rights or through access strategies. It also distinguishes people in the community between farmers and non farmers; meaning that only when having land for agriculture, the community recognizes a persons' need and, therefore, accepts it as a legitimate candidate for receiving irrigation water. Finally aspects of social status, family networks and influence within the community will determine the easiness of acquiring water rights. The third factor refers to the resources needed to materialize water rights, depending on the forms of acquisition. As data show, there are differences in water allocation between and within the different communities. These differences distinguish groups of advantaged and disadvantaged people, which can be a potential source of conflict as the water becomes scarcer. It also shows the complexity of this area in relation to water for agricultural purposes and calls attention to policies regarding water management that seeks for social justice and sustainable management of water.

\section{References}

[1] Cremers, L., Ooijevaar, M. \& Boelens R. Institutional reform in the Andean irrigation sector: Enabling policies for strengthening local rights and water management, Natural Resources Forum, 29, pp. 37-50, 2005.

[2] Water Law and Indigenous Rights Programme (WALIR), Indigenous water rights, local water management, and national legislation. WALIR Studies 2, Wageningen University and UN ECLAC: Wageningen, 2002.

[3] De Vos H., Boelens, R. \& Bustamante, R. Formal Law and Local Water Control in the Andean Region: A Fiercely Contested Field, Water Resources Development, 22(1), pp. 37-48, 2006.

[4] Boelens, R. The Politics of Disciplining Water Rights, Development and Change, 40(2), pp. 307 - 331, 2009.

[5] Hendriks, J. Legislación de aguas y gestión de sistemas hídricos en países de la región andina (Chapter 2). Derechos Colectivos y Políticas Hídricas en la Región Andina, eds. P. Urteaga \& Boelens, R., IEP: Lima, pp. 47-112, 2006. 
[6] Hendriks, J. Water Laws, Collective Rights and System Diversity in the Andean Countries (Chapter 8). Out of the Mainstream - Water Rights, Politics and Identity, eds. R. Boelens, Getches, D. \& Guevara-Gil, A., Earthscan: UK, pp. $165-180,2010$.

[7] Boelens, R. \& Zwarteveen, M. Prices and Politics in Andean Water Reforms, Development and Change, 36(4), pp. 735 - 758, 2005.

[8] Boelens, R. \& Doornbos, B. The Battlefield of Water Rights: Rule Making Amidst Conflicting Normative Frameworks in the Ecuadorian Highlands, Human Organization, 60(4), pp. 343-355, 2001.

[9] Perrault, T. Custom and Contradiction: Rural Water Governance and the Politics of Usos y Costumbres in Bolivia's Irrigators' Movement, Annals of the Association of American Geographers, 98(4), pp. 834 - 854, 2008.

[10] Rojas, F. \& Montenegro, E. Potencial hídrico superficial y subterráneo del abanico de Punata, Centro AGUA: Cochabamba, 2007.

[11] Swyngedouw, E., Neither Global Nor Local: 'Glocalization' and the Politics of Scale (Chapter 6). Spaces of Globalization: Reasserting the Power of the Local, ed. K.R. Cox, Guilford Press: New York, pp. $137-$ 166, 1997.

[12] Boelens, R. The Rules of the Game and the Game of the Rules. Normalization and resistance in Andean water control, PhD Thesis, Wageningen University: The Netherlands, 573p, 2008.

[13] Wester, P. Shedding the Waters: Institutional Change and Water Control in the Lerma-Chapala Basin, Mexico, PhD Thesis, Wageningen University: The Netherlands, 2008.

[14] Centro A.G.U.A. Base de Datos Pucara, 2009.

[15] Del Callejo, I. \& Vásquez, S. Caracterización y cambios en el uso del agua en Punata, Centro AGUA: Cochabamba, 2007.

[16] Uzeda, A., (Dis) cursos de agua. Derechos, estrategias y legitimación en los sistemas de riego Punata - Tiraque, Wageningen University, 1994.

[17] Sejas, L.X. Procesos sociales en la construcción de la Asociación de Regantes en Punata. Facultad de Ciencias Económicas y Sociología UMSS: Cochabamba, 1997.

[18] Saravia, R. I. Gestión de agua de las diferentes fuentes en la comunidad de Pucara. Facultad de Ciencias Agrícolas, Pecuarias, Forestales y Veterinarias "Martín Cárdenas" - UMSS: Cochabamba, 1998.

[19] Montaño, H. Sostenibilidad de Sistemas de Riego Manejado por Campesinos en la Asociación de Riego y Servicios Punata. Facultad de Ciencias Agrícolas, Pecuarias, Forestales y Veterinarias "Martín Cárdenas" - UMSS: Cochabamba, 1995.

[20] Delgadillo, O. \& Lazarte, N. Gestión de los sistemas de aprovechamiento de agua en el municipio de Punata, Centro AGUA: Cochabamba, 2007.

[21] Gerbrandy, G., Reparto de Agua en un Río en los Valles Interandinos (Chapter 7.4). Buscando la Equidad, eds. R. Boelens \& Davila, G., Van Gorcum: Assen, pp. 344-355, 1998. 
[22] Trawick, P. The Moral Economy of Water: Equity and Antiquity in the Andean Commons, American Anthropologist, New Series, 103(2), pp. 361 $-379,2001$.

[23] Antezana, R.M. Rol de la mujer en la gestión del riego en tres comunidades del abanico de riego Punata. Facultad de Ciencias Agrícolas y Pecuarias UMSS: Cochabamba, 1994.

[24] Tuijtelaars, C., Pozo, M.E., Antezana, R. M. \& Saavedra, R. Mujer y Riego en Punata. Aspectos de Género. Situación de uso, acceso y control sobre el agua para riego en Punata, PEIRAV: Cochabamba, 1994. 